Diabetologia 7, 379-385 (1971)

(C) by Springer-Verlag 1971

\title{
Analysis of the Inhibitory Effect of Biguanides on Glucose Absorption: Inhibition of Active Sugar Transport*
}

\author{
W.F. Caspary and W. Creutzfeldt
}

Division of Gastroenterology and Metabolism, Department of Medicine, University of Göttingen, W. Germany

Received: March 10, 1971, accepted: July 27, 1971

Summary. The effect of biguanides (phenethylbiguanide, butylbiguanide and dimethylbiguanide) on absorption of actively transported sugars was examined by incubating rings of hamster small intestine in vitro. Biguanides inhibited transport of D-glucose, D-galactose and 3-0-methyl-D-glucose but had no effect on the transport of $D$-fructose. Inhibition of $D$-xylose transport could only be demonstrated if concentrations far below halfmaximal saturation concentration $(\mathrm{Km})$ were used $\left(10^{-5} \mathrm{M}\right)$, but not with concentrations approaching concentrations during a $\mathrm{D}$-xylose tolerance test $(18 \mathrm{mM})$. Formation of lactate by intestinal tissue was increased in presence of biguanides using $D$-glucose or $D$-fructose as substrates. The minimal inbibitory concentrations on transport of $\mathrm{D}$-galactose were $10^{-3} \mathrm{M}$ for phenethylbiguanide, $2 \times 10^{-3} \mathrm{M}$ for butylbiguanide and $6 \times 10^{-3} \mathrm{M}$ for dimethylbiguanide. The metabolite of phenethylbiguanide, 1 -(4-hydroxy- $\beta$-phenethyl)-biguanide, did not affect glucose uptake but increased glucose metabolism to some extent. The demonstrated inhibition of active intestinal transport in vitro may be the mechanism for the decreased absorption of glucose observed by other authors in vivo in man and animals after biguanides.

Analyse de l'effet inhibiteur des biguanides sur l'ab. sorption de glucose: inhibition du transport actif de sucre

Résumé. En incubant les anneaux de I'intestin grêle chez le hamster in vitro, on a pu examiner l'effet des biguanides (phénéthylbiguanide, butylbiguanide et diméthylbiguanide) sur l'absorption des sucres transportés activement. Les biguanides ont inhibé le transport de D-glucose, de D-galactose et de 3-0-méthyl-D-glucose, mais n'ont eu aucun effet sur le transport de D-xylose et de D-fructose. La formation de lactate par les tissus in. testinaux s'est accrue en présence des biguanides en utilisant le D-glucose et le D-fructose en tant que substratum. Les concentrations minimales inhibitrices du transport de $\mathrm{D}$-galactose étaient de $10^{-3} \mathrm{M}$ pour le phénétylbiguanide, $2 \times 10^{-3} \mathrm{M}$ pour le butylbiguanide et $6 \times 10^{-3} \mathrm{M}$ pour le diméthylbiguanide. Le métabolite du phénéthylbiguanide, 1-(4-hydroxy- $\beta$-phénéthyl)-biguanide, n'a pas affecté la captation de glucose, mais a augmenté le métabolisme du glucose dans une certaine proportion. Conformément à de récents rapports de la littérature, on conclue que l'inhibition du transport intestinal peut être un facteur important dans le mécanisme de l'action des biguanides en ce qui concerne le diabète sucré et l'obésité.

Analyse des Einflussen von Biguaniden auf die Glucose Absorption: Hemmung des altiven Zuckertransportes

Zusammenfassung. Es wurde der Einfluß verschiede. ner Biguanide (Phenäthylbiguanid, Butylbiguanid und Dimethylbiguanid) auf die Resorption verschiedener aktiv transportierbarer Zucker am Hamsterdünndarm in vitro untersucht. Biguanide hemmten den Transport von D-Glucose, D-Galaktose und 3-0-Methyl-D-Glucose, beeinflussten jedoch den Transport von D-Fructose nicht. Eine Hemmung des D-Xylose-Transportes konnte nur gezeigt werden, wenn Konzentrationen weit unter der halbmaximalen Sättigungskonzentration für D-Xylose benutzt wurden $\left(10^{-5} \mathrm{M}\right)$, jedoch nicht bei Konzentrationen, wie sie annähernd während eines D-Xylose-Toleranztestes erreicht werden $(18 \mathrm{mM})$. Die Lactatbildung im Darmgewebe aus Glucose und Fructose war in Gegenwart von Biguaniden deutlich gesteigert. Die minimalen Hemm. konzentrationen für den Galaktosetransport betrugen $10^{-3} \mathrm{M}$ für Phenäthylbiguanid, $2 \times 10^{-3} \mathrm{M}$ für Butylbiguanid und $6 \times 10^{-3} \mathrm{M}$ für Dimethylbiguanid. Das nicht blutzuckersenkend wirkende Abbauprodukt des Phenäthylbiguanid, 1-(4-hydroxy- $\beta$-phenäthyl)-Biguanid, hatte keinen Einfluß auf die Glucoseaufnahme, bewirkte aber eine Steigerung des Abbaues der aufgenommenen Glucose. Die gezeigte Hemmung des aktiven intestinalen Zuckertransportes in vitro könnte der Mechanismus der herabgesetzten Glucoseresorption nach Biguanidgabe in vivo sein, der von anderen Autoren bei Mensch und Tier beschrieben wurde.

Key-words: Biguanides, phenethylbiguanide, butyl biguanide, methylbiguanide, active sugar transport, intestinal absorption, hamster small intestine, lactate formation.

\section{Introduction}

Various mechanisms have been proposed to explain the therapeutic action of biguanides in diabetes mellitus and obesity [18]. The validity of the hypothesis that biguanides lower blood glucose levels of

* Part of this work has been presented at the 5th annual meeting of the German Diabetes Society, Bad Godesberg, May 1970 and the 7th Congress of the International Diabetes Federation, Buenos Aires, August 1970. diabetics by a direct effect on peripheral glucose metabolism has been seriously questioned. Concentrations of biguanides used to induce effects in vitro have been several orders of magnitudes higher than those which actually are achieved after a therapeutic oral dose of biguanides [18]. It has been shown, however, that phenethylbiguanide accumulates selectively in the liver and in the gastrointestinal tract of rats [30], and butylbiguanide achieved its highest concentrations in small intestine of mice [33]. Consequently, in the in- 
testine concentrations used for studies in vitro may be achieved after an oral therapeutic dose of biguanides. Observations that therapeutic doses of biguanides markedly improved glucose tolerance after an oral glucose load [19, 20,23], but did not affect glucose tolerance after intravenous glucose administration [19, $20,23]$ indicate that the effect of biguanides on intestinal transport of D-glucose may be of main importance for the mechanism of action of these drugs. The main difference of these recent reports from earlier less impressive results on the effect of biguanide treatment on the oral glucose tolerance test is the fact that the biguanides were administered shortly before the glucose load.

Biro et al. [8] already observed that phenethylbiguanide reduced glucose absorption from rat small intestine in vivo. Creutzfeldt et al. [17], Förster et al. [21], and Ghareb et al. [22] found that butylbiguanide had an indirect effect on intestinal absorption of glucose in rats consisting in an impairment of the passage from the stomach to the intestine. Czyzyk et al. [19] demonstrated by infusing glucose through loops of dog small intestine an inhibitory effect of butylbiguanide on glucose absorption in vivo. He also observed that pretreatment with phenethylbiguanide reduced blood glucose in mild diabetes after glucose administration by an oral load or intraduodenal drip.

Animal experiments in rats and guinea pigs have also shown that pretreatment of the animals with biguanides decreased subsequent transport of D-glucose in vitro using the everted-sac technique $[22,24,25]$. The intestinal transport system for sugars has been well characterized by Crane and coworkers using techniques, in vitro especially in regard to its specificity and transport kinetics $[14,15]$.

The purpose of this report is to analyze the inhibitory effect of biguanides on intestinal absorption of glucose. Transport of several substrates exhibiting high and low affinities for the common sugar transport system will be measured in the presence of biguanides, in order to find out whether the inhibitory effect of biguanides is an effect on 1. glucose transport alone; 2. all substrates using the common sugar transport system or 3. all intestinal active transport mechanisms.

\section{Methods}

The present experiments were performed in vitro by the technique of Crane and Mandelstam [13] as modified in a more recent publication $[9,10]$. Hamsters, $80 \pm 15 \mathrm{~g}$ in weight, were fasted overnight. Rings of everted hamster small intestine, 200-300 mg net weight, were placed in $25 \mathrm{ml}$ Erlenmeyer flasks, containing $5 \mathrm{ml}$ or $10 \mathrm{ml}$ of Krebs-Henseleit phosphate buffer with the appropriate substrates added. The buffer was gassed with pure oxygen. D-mannitol was used as a marker for extracellular space [9].
Compounds. D-glucose, D-galactose, D-xylose and D-fructose were obtained from Serva (Heidelberg). 3-0-Methyl-D-glucose was a gift from Ayerst Laboratories (New York). Labelled compounds, ${ }^{14} \mathrm{C}-\mathrm{D}$-glucose, ${ }^{14} \mathrm{C}$-D -galactose, ${ }^{14} \mathrm{C}$-3-0-methyl-D-glucose ${ }^{3} \mathrm{H}$-Dmannitol were obtained from New England Nuclear. Phenethylbiguanidehydrochloride was kindly provided by USV Pharmaceutical Corporation (New York), butylbiguanide was provided by Chemie Grünenthal (Stolberg/Rhld.), dimethylbiguanide was obtained from Dr. Heinz Haury (München). 1-(4-hydroxy- $\beta$ phenethyl)-biguanide was a gift of Dr. R. Beckmann, Chemie Grünenthal (Stolberg/Rhld.).

Analytical methods. Incubations were terminated by removal of the tissue, which was further processed as described by Crane and Mandelstam [13]. ${ }^{3} \mathrm{H}-\mathrm{D}$ mannitol, ${ }^{14} \mathrm{C}-\mathrm{D}$-glucose, ${ }^{14} \mathrm{C}-\mathrm{D}$-galactose, ${ }^{14} \mathrm{C}-3-0$ methyl-glucose were assayed by a Packard Liquid Scintillation System. D-glucose was assayed by the glucose oxidase method using the Biochemica Test Combination (Boehringer, Mannheim). D-xylose was determined according to the method of Roe [27]. Lactate was measured with the Biochemica Test Combination (Boehringer, Mannheim).

Calculation of data. Results are expressed in

$$
\text { per cent filling }=100 \times \frac{\mu \text { moles } / \mathrm{ml} \text { tissue water }}{\mu \mathrm{moles} / \mathrm{ml} \text { initial medium }}
$$

assuming a water content of approximately $80 \%$ of the tissue wet weight [13]. All data are corrected for the D-mannitol space [10].

\section{Results}

Sugar transport in the intestine has been characterized as a $\mathrm{Na}^{+}$-dependent, phlorizin-sensitive, energy dependent, carrier-mediated process of accumulation against an electrochemical concentration gradient [13, 14]. D-glucose $(K m=1.5 \mathrm{mM})$ [14] exhibits the highest affinity for the intestinal sugar transport system. The affinity of 3-0-methyl-D-glucose $(K m=22 \mathrm{mM})$ [10], a non-metabolizable sugar analogue is considerably lower. The 'weakest' substrates for the common sugar pathway are L-glucose $(K m=65 \mathrm{mM})$ [9] and D-xylose $(K m=100-300 \mathrm{mM})$ [1].

Since D-glucose is the main and best substrate we tested the effect of phenethylbiguanide on the uptake of D-glucose (Fig. 1). No significant inhibitory effect could be observed up to an incubation time of $5 \mathrm{~min}$. After 45 min. of incubation $80.8 \%$ of the radioactivity of ${ }^{14} \mathrm{C}$-D -glucose could be recovered as D-glucose. This corresponds to reports in the literature for rat intestine where D-glucose can be metabolized to quite an extent [3]. In the presence of phenethylbiguanide $\left(10^{-2} \mathrm{M}\right)$ uptake of ${ }^{14} \mathrm{C}-\mathrm{D}$-glucose was inhibited by $64.4 \%$, none of which could be found as 'true' D-glucose in the tissue. Therefore phenethylbiguanide decreased influx of $\mathrm{D}$-glucose while simultaneously increasing the meta- 
bolism of D-glucose entering the intestinal epithelial cells.

If rings of hamster small intestine were preincubated for $30 \mathrm{~min}$ in the presence of phenethylbiguanide, and subsequently the transport capacity for D-galactose was tested without phenformin present in the metabolizable substrates should be used. Therefore transport of $\mathrm{D}$-galactose, which is very poorly metabolized [15], of 3-0-methyl-D-glucose [10], a non-metabolizable sugar analogue, and D-xylose [1] was measured and the effect of phenethylbiguanide and butylbiguanide was examined. If biguanides exert their inhibi-

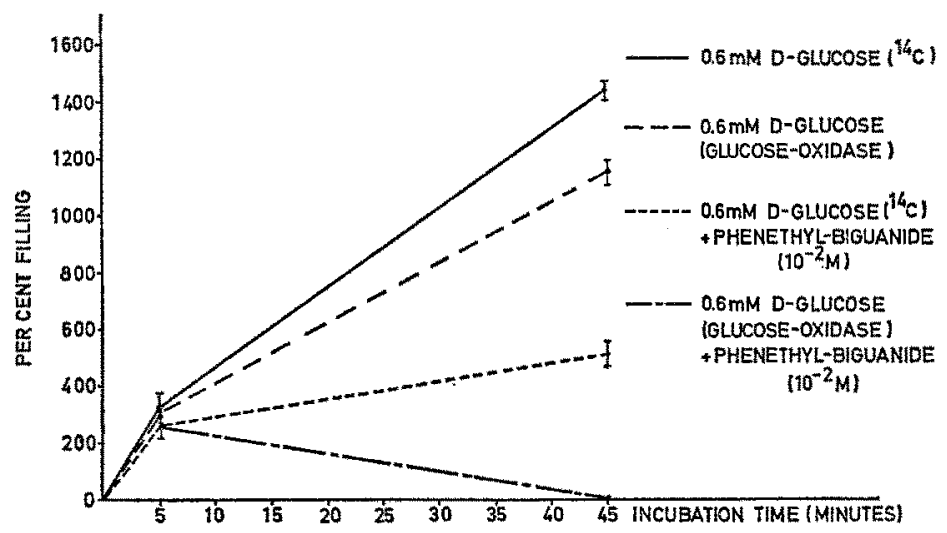

Fig. 1. Effect of phenethylbiguanide on uptake of ${ }^{14} \mathrm{C}-\mathrm{D}$-glucose by hamster small intestine in vitro. Rings of everted hamster small intestine were incubated for different time periods in Krebs-Henseleit phosphate buffer. Results are given as means \pm SEM $(n=5)$

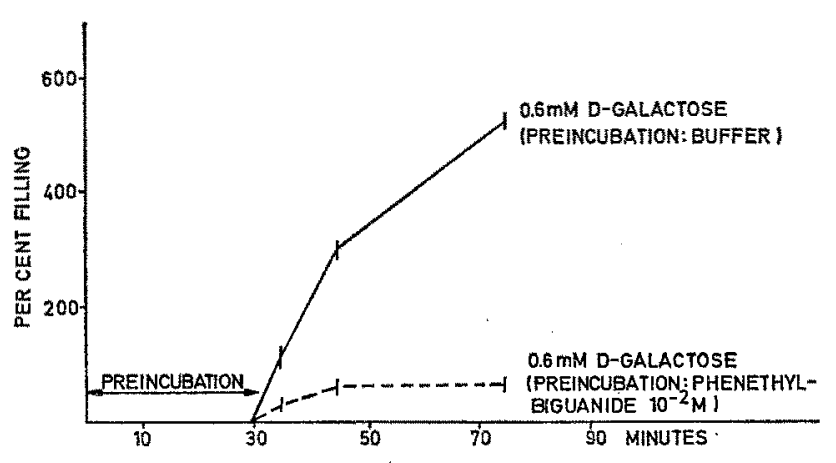

Fig. 2. Effect of pre-incubation with phenethylbiguanide on subsequent intestinal transport of D-galactose. Rings of everted intestinal tissue were pre-incubated for $30 \mathrm{~min}$ in Krebs-Henseleit phosphate buffer or in buffer plus phenethylbiguanide. Tissue was then transferred to a new medium containing buffer and $0.6 \mathrm{mM}{ }^{14} \mathrm{C}-\mathrm{D}$-galactose, and incubated for the time periods indicated. Results are given as means $\pm \operatorname{SEM}(n=5)$

medium we found an immediate and stronger inhibitory effect (Fig. 2). No longer is intracellular concentration against a gradient achieved. Since biguanides are known to inhibit respiration thus leading to an increase in anaerobic glycolysis $[28,18]$, we examined the effect of biguanides on lactate formation of intestinal tissue from D-glucose. With increasing concentrations of phenethylbiguanide glucose accumulation in the tissues decreased and formation of lactate increased (Fig. 3).

As metabolism of D-glucose occurs during the course of transport even in the absence of phenethyl. biguanide [3] (Fig. 1), D-glucose is not a suitable compound to measure transport. Instead, poorly or non-

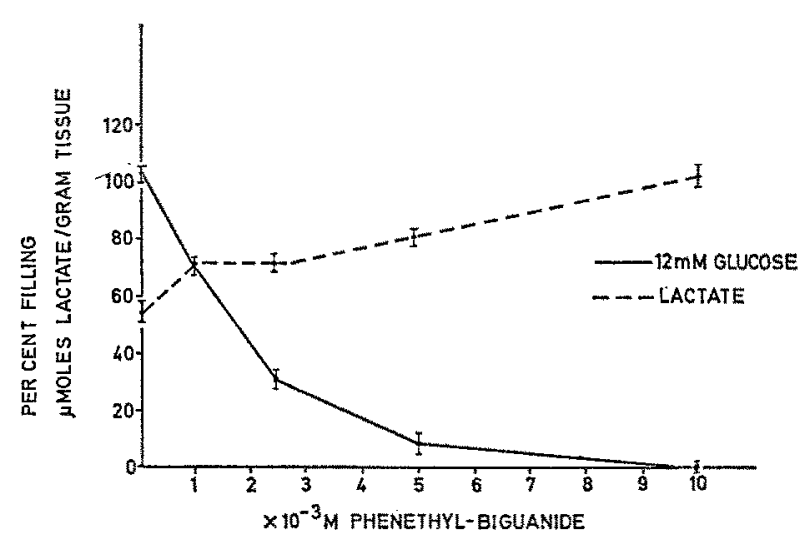

Fig. 3. Effect of phenethylbiguanide on accumulation of $\mathrm{D}$-glucose and lactate formation from $\mathrm{D}$-glucose by hamster small intestine in vitro. Rings of everted hamster small intestine were incubated for 45 minutes with $18 \mathrm{mM}$ D-glucose in the presence of various concentrations of phenethylbiguanide. Intracellular concentration of D. glucose is expressed in \%-filling, lactate production is expressed in pmoles of lactate formed $/ \mathrm{g}$ of tissue wet weight/45 min. Results are given as means \pm SEM $(n=6)$

tory action by affecting the common sugar binding site, uptake of all substrates should be affected as in the case of phlorizin [14] or sulphydrylgroup reagents such as n-ethyl-maleimide. Transport of D-galactose was more strongly inhibited than transport of the 'poorer' substrate 3-0-methyl-D-glucose (Fig. 4). Uptake of D-xylose was not inhibited using $18 \mathrm{mM}$ D-xylose as the substrate. One has to keep in mind that with D-xy. lose as a substrate, an intracellular concentration against a gradient has not been achieved, even tough its transport shows all the criteria for acceptance as a 
substrate for the common sugar transport system [1, $14]$.

In order to find out the lowest inhibitory concentrations of phenethylbiguanide, butylbiguanide and dimethylbiguanide, we incubated rings of hamster small intestine with different concentrations of biguanides.

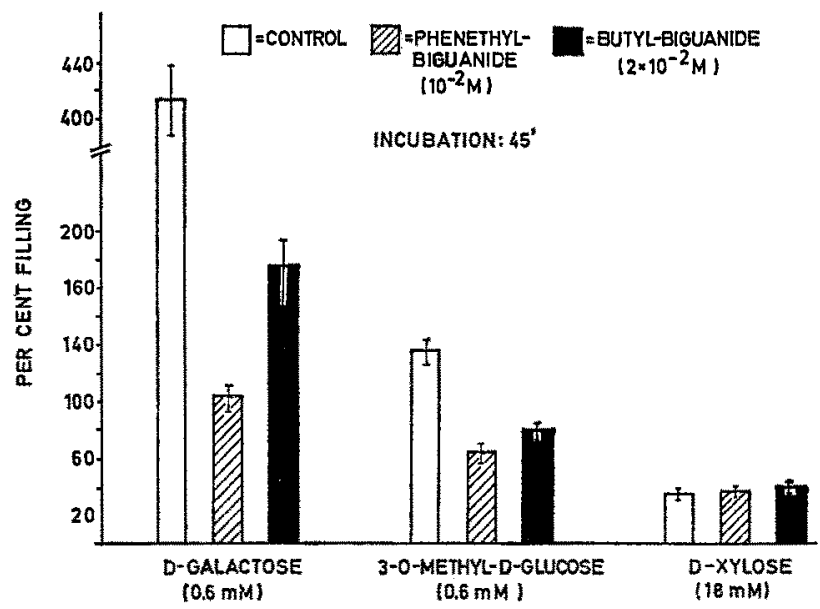

Fig. 4. Comparative effect of phenethylbiguanide and butylbiguanide on intestinal transport of D-galactose, 3-0-methyl-D-glucose and D-xylose. Intestinal rings were incubated for 45 minutes with the appropriate substrates, biguanides were added as indicated in the graph. Results are given as means $\perp$ SEM $(n=4)$

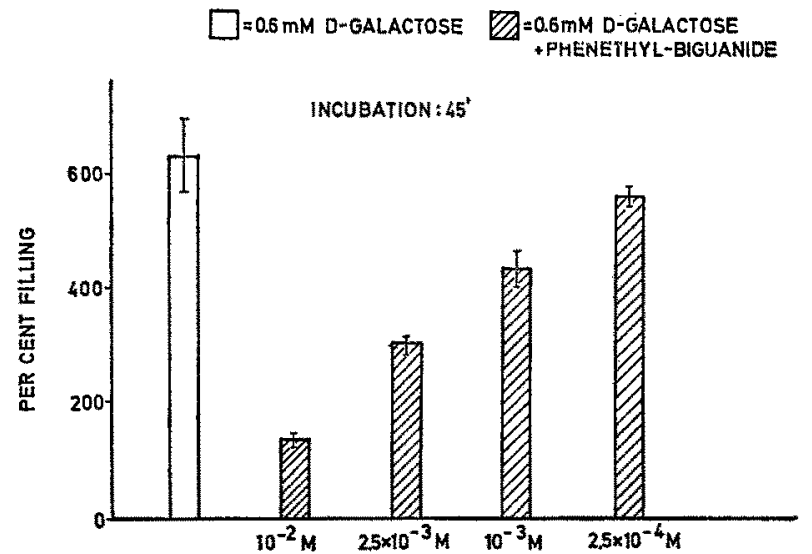

Fig. 5. Inhibition of intestinal transport of D-galactose by different concentrations of phenethylbiguanide. Intestinal rings were incubated for 45 minutes with $0.6 \mathrm{mM}{ }^{14} \mathrm{C}-\mathrm{D}$ -

galactose. Results are given as means $\pm S E M(n=6)$

Phenethylbiguanide exerted an inhibitory effect on transport of D-galactose even at a concentration of $10^{-3} \mathrm{M}$ (Fig. 5). The lowest inhibitory concentration of butylbiguanide was $2 \times 10^{-3} \mathrm{M}$ (Fig. 6). Dimethylbiguanide (not shown) was inhibitory at a concentration of $6.5 \times 10^{-3} \mathrm{M}$.

The metabolite of phenethylbiguanide, 1-(4-hydroxy- $\beta$-phenethyl)-biguanide, is known to have no blood-glucose-lowering effect in the mouse [4] and to be less potent in the rat, compared with the non- hydroxylated form [30]. If this compound would affect intestinal transport in equimolar concentrations to the same extent as phenethylbiguanide, one might consider the inhibitory effect of biguanides on intestinal transport as an unspecific side-effect having no significance for the blood glucose-lowering effect of these drugs in

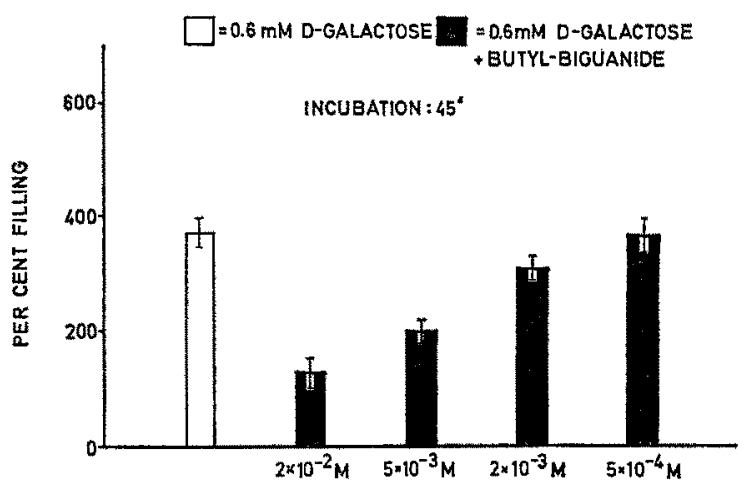

Fig. 6. Inhibition of $D$-galactose transport by various concentrations of butylbiguanide. Results are given as means $\pm \mathrm{SEM}(\mathrm{n}=6)$

diabetics. 1-(4-hydroxy- $\beta$-phenethyl)-biguanide did not inhibit uptake of $\mathrm{D}$-glucose at a concentration of $10^{-2} \mathrm{M}$; however, an increase of intracellular glucose metabolism was induced as measured by a decreased amount of D-glucose in the tissue (Table 1 ).

D-fructose is absorbed by the intestine but it is not actively transported $[14,15]$. Intracellularly, Dfructose, however, can be converted to D-glucose which then may be actively transported [15]. There are two pathways for the conversion of fructose to glucose, both of which require ATP: one, in which the initial reaction is the formation of fructose-6-phosphate catalyzed by hexokinase and the other, by which fructose-1-phosphate formation is catalyzed by fructokinase [15]. Experiments were done by incubating rings of intestine with $D$-fructose in the presence and absence of phenethylbiguanide. As expected; phenethylbiguanide $\left(10^{-2} \mathrm{M}\right)$ did not affect intracellular concentration of fructose after an incubation of $45 \mathrm{~min}$ with $18 \mathrm{mM}$ D-fructose; however, after incubation with phenethylbiguanide glucose formed from fructose was nearly absent. This may have been due to depressed intracellular conversion of fructose to D-glucose or, more likely, due to an increase of anaerobic glycolysis of glucose resulting in an increased formation of lactate (Table 2).

\section{Discussion}

The results presented show that biguanides do inhibit transport of actively transported sugars in vitro. This inhibition was strongest for substrates achieving highest accumulations in the intestinal epithelial cells. These findings agree with observations of other investigators that administration of biguani- 
des to rats and guinea pigs in vivo resulted in a subsequent decreased transport of D-glucose in vitro [22, $24,25]$. These authors $[22,24,25]$ carried out their experiments with the everted-sac technique [32], using D-glucose as a substrate and measured glucose at the mucosal and serosal side of the intestine, taking muco- glucose and also to an increase of glucose metabolism in the intestinal wall of patients pretreated with biguanides. Biguanides did not have an effect on transport of D-xylose, which is in agreement with several studies in vivo $[2,5,18,31]$, and proves that the $D$-xylose tolerance test is an inadequate parameter to use if one

Table 1. Effect of phenformin and its metabolite 1-(4-hydroxy- $\beta$-phenethyl)-biguanide on uptake of D-glucose by hamster small intestine in vitro

\begin{tabular}{lcccc}
\hline Substrate & $\begin{array}{c}\% \text {-filling } \\
\left({ }^{4} \mathrm{C}\right)\end{array}$ & $\begin{array}{c}\% \text {-inhibition } \\
\text { (GOflling }\end{array}$ & $\begin{array}{c}\% \text {-inhibition } \\
(\mathrm{GOD})\end{array}$ \\
\hline $\begin{array}{l}\text { Control } \\
(6 \mathrm{mM} \text { D-glucose })\end{array}$ & $663 \pm 15$ & - & $626 \pm 26$ & - \\
$\begin{array}{l}\text { Plus phenformin } \\
\left(10^{-2} \mathrm{M}\right)\end{array}$ & $132 \pm 14$ & 80 & $68 \pm 10$ & 89.1 \\
$\begin{array}{l}\text { Plus 1-(4-hydroxy- } \beta- \\
\text { phenethyl)-biguanide } \\
\left(10^{-2} \mathrm{M}\right)\end{array}$ & $631 \pm 43$ & 5 & $492 \pm 18$ & 21.5 \\
\hline
\end{tabular}

Rings of hamster small intestine were incubated for $45 \mathrm{~min}$ in Krebs-Henseleit phosphate buffer.

Results are expressed as means $\pm \operatorname{SEM}(n=5)$

Table 2. Effect of phenethylbiguanide on uptake of D.fructose, formation of D-glucose from fructose and lactate formation

\begin{tabular}{llll}
\hline Substrate & $\begin{array}{l}\text { intracellular D-fructose } \\
(\mu \text { moles } / \mathrm{ml} \text { tissue water) }\end{array}$ & $\begin{array}{l}\text { formation of D-glucose } \\
\text { (pmoles/g tissue wet-w.) }\end{array}$ & $\begin{array}{l}\text { lactate formation } \\
\text { ( } \mu \text { moles/g tissue wet-w.) }\end{array}$ \\
\hline $\begin{array}{l}\text { D-fructose }(18 \mathrm{mM}) \\
\begin{array}{l}\text { D-fructose }(18 \mathrm{mM}) \\
\text { plus phenethylbiguanide } \\
\left(10^{-2} \mathrm{M}\right)\end{array}\end{array}$ & $\mathbf{3 . 4 8} \pm 0.72$ & $7.3 \pm 0.64$ & $23.8 \pm 3.3$ \\
\hline
\end{tabular}

Rings of hamster small intestine were incubated for $45 \mathrm{~min}$ in Krebs-Henseleit phosphate buffer. Tissue and medium were analyzed for D-glucose and lactate.

Results are given as means \pm SEM $(n=6)$

sal-serosal concentration differences of $D$-glucose as a measure for transport, but did not analyze the tissue compartment for glucose. Since D-glucose can be meta. bolized to a considerable extent in the small intestinal wall [3] their studies could not distinguish whether the decreased amount of D-glueose appearing at the serosal side of the intestine from animals pretreated with phenethylbiguanide, was due to a decreased uptake of D-glucose or an increased intracellular metabolism of D-glucose. By using non-metabolizable substrates for the intestinal sugar transport system we could show that indeed uptake of sugars is decreased by biguanides.

If a metabolizable substrate, like D-glucose, is used there is in addition an increase in anaerobic gly. colysis in presence of biguanides, thus leading to a lower intracellular glucose concentration and a decrease of the amount of D-glucose appearing in the serosal compartment of a preparation in vitro. The decreased blood glucose response after oral glucose administration as reported by Czyzyk et al. $[19,20]$ and Hollobaugh [23] in maturity-onset diabetics as well as in normal adults, could be, judging from our results in vitro, due to a decreased or delayed transport of $D$. wants to make conclusions on glucose absorption. D-xylose is a 'weak' substrate of the common intestinal sugar transport system [14], whereas D-glucose has a very high affinity for the system [14] and in addition can be metabolized to quite a considerable extent before appearing in the portal venous system [15]. In our experiments we used $18 \mathrm{mM} D$-xylose as the substrate approaching the conditions in vivo during the xylose tolerance test. However, an inhibitory effect can be expected only if concentrations of $D$ xylose far below $K m$ or tracer amounts are used, because with concentrations of $5.4 \times 10^{-5} \mathrm{M}$ D-xylose Bihler et al. succeded in achieving concentrations against a gradient [5a]. As expected, in additional experiments using ${ }^{14} \mathrm{C}-\mathrm{D}$-xylose in $10^{-5} \mathrm{M}$ cold carrier substance we could demonstrate an inhibitory effect of phenethylbiguanide $\left(10^{-2} \mathrm{M}\right)$ on uptake of $\mathrm{D}$-xylose (23\% inhibition).

Berger et al. [7] have shown an increase in portal lactate concentration after an oral load of D-glucose in patients pretreated with dimethylbiguanide. Our results in vitro confirm this observation, since phenethylbiguanide increased lactate production from $D$-glucose by intestinal tissue. Formation of lactate from D- 
fructose was also increased in the presence of phenethylbiguanide (Table 2). Transport of D-fructose, which is not actively transported in the intestine, was not affected by biguanides. The amount of glucose, how. ever, formed from $D$-fructose was much less in presence of biguanides. This may be due to an increase of anaerobic glycolysis of the glucose formed from D-fructose, thus leading to an increased lactate production or an inhibition of the conversion of D-fructose to D-glucose catalyzed in the intestinal mucosal wall by hexokinase or fructokinase and requiring ATP.

The fact that the inhibitory action on active transport, and possibly on any reaction requiring energy in the intestine (like phosphorylation) is exerted only by known blood-glucose-lowering biguanides (phenethylbiguanide, butylbiguanide, dimethylbiguanide) and not by a biguanide which has no [4] or only a small [30] effect on lowering blood glucose, like 1-(4-hydroxy- $\beta$ phenethyl)-biguanide, suggests that the effect of biguanides on intestinal absorption may be an important factor in the mechanism of action of these drugs. Inhibition of active sugar transport by biguanides is not specific for the D-glucose transport system. Active transport of myo-inositol, structurally very similar to D-glucose but entering the intestinal mucosal cell by a route different from the D-glucose pathway [11], is also inhibited by phenethylbiguanide [12]. Active transport of amino acids $[12,18]$ in hamster small intestine, and active intestinal transport of calcium in rat duodenum is further inhibited by biguanides $[12,18]$.

The concentrations of biguanides used to induce effects in muscle and adipose tissue in vitro were much higher than those achieved in vivo by therapeutic doses. This is not true for the intestine. An inhibition of glucose absorption by biguanides has been reported already in diabetics $[19,20]$ and in normals [23]. It is not yet possible to relate quantitatively the effects of biguanides on intestinal transport to the overall therapeutic action of these drugs in patients with diabetes mellitus. An increased absorption of glucose has been shown by several authors in alloxan-diabetic rats using techniques in vitro $[16,26]$, and in juvenile diabetics with the intestinal perfusion technique [29]. However, applying different methods in vivo Levinson et al. [24a] were unable to confirm this in alloxan-diabetic rats. Further studies are necessary to find out whether the diabetic state really is associated with an increased and accelerated absorption of glucose.

If the earlier reports $[16,26,29]$ can be confirmed, inhibition of glucose absorption by biguanides may be of special importance in the mechanism of action of these oral antidiabetic drugs.

Acknowledgements: We wish to thank Dr. R. Beckmann (Chemie Grünenthal) for providing us with a small quantity of 1 -(4-hydroxy- $\beta$-phenethyl)-biguanide and Miss A. Thinius for skillful technical assistance. This work was supported by a grant from the Deutsche Forschungsgemeinschaft (Ca 71/1).

\section{References}

1. Alvarado, F.: D-xylose active transport in the hamster small intestine. Biochim. biophys. Acta 112 $292-306(1966)$.

2. Appels, A., Willms, B., Sickinger, K.: Verhalten der D-Xylose-Resorption unter Monotherapie mit $\mathrm{N}_{1}$ Butylbiguanid. Diabetologia 6, 71 (1970).

3. Atkinson, R.M., Parsons, B.J., Smyth, D.H.: Intestinal absorption of glucose. J. Physiol. 135, 581589 (1957).

4. Beckmann, R.: Ưber die Resorption und den biologischen Abbau von 1-( $\beta$-phenäthyl)-biguanid (Phenformin). Diabetologia 3, 368-376 (1967).

5. Berchtold, P., Bolli, P., Arbenz, U., Keiser, G.: Intestinale Absorptionsstörung infolge Metforminbehandlung. Diabetologia 5, 405-412 (1969).

5a. Bihler, I., Kim, N.D., Sawh, P.C.: Active transport of L-glucose and D-xylose in hamster intestine, in vitro. Canad. J. Physiol. Pharmacol. 47, 525-531 (1969).

6. Berger, W.: The effect of a single dose of $1 \mathrm{~g}$ dimethylbiguanide (DMB) on the utilisation of intravenous and orally administered glucose and galactose. Diabetologia 4, 382 (abstract) (1968).

7. - Künzli, H. : Effect of dimethylbiguanide on insulin, glucose and lactic acid contents in portal vein blood and peripheral venous blood in the course of intraduodenal glucose tolerance test. Diabetologia 6, 37 (abstract) (1970).

8. Biro, L., Bányász, T., Kovacs, M.B., Bajor, M.: Die Wirkung des Phenäthylbiguanids auf die Glukoseresorption. Klin. Wschr. 39, 760-762 (1961).

9. Caspary, W.F., Crane, R.K.: Inclusion of L-glucose within the specificity limits of the active sugar trans. port system of hamster small intestine. Biochim. biophys. Acta 163, 395-400 (1968).

10. - Stevenson, N.R., Crane, R.K.: Evidence for an intermediate step in carrier-mediated sugar translocation across the brush border membrane of hamster small intestine. Biochim. biophys. Acta 193, 168-178 (1969).

11. - Active transport of Myo-Inositol and its relation to the sugar transport system in hamster small intestine. Biochim. biophys. Acta 203, 308-316 (1970).

12. - Effect of biguanides on intestinal transport of sugars, amino acids, and calcium. Naunyn-Schmiedebergs Arch. Pharmakologie 269, 421 (1971).

13. Crane, R.K., Mandelstam, P.: The active transport of sugars by various preparations of hamster intestine. Biochim. biophys. Acta 45, $460-476$ (1960).

14. - Absorption of sugars. In: Handbook of Physiology, Section 6, Vol. 3, Alimentary Canal, p. 1323-1354. Ed. C.F. Code. Washington, D.C.: Amer. Physiol. Society 1968.

15. - Intestinal absorption of sugars. Physiol. Rev. 40, $789-825(1960)$.

16. - An effect of alloxan diabetes on the active transport of sugars by rat small intestine in vitro. Biochim. biophys. Res. Commun. 4, 436-440 (1961).

17. Creutzfeldt, W., Söling, H.D., Moench, A., Rauh, E., Bol, M.: Die Wirkung von $\mathrm{N}_{1}, \mathrm{n}$-Butylbiguanid (W 37) und $\mathrm{N}_{1}, \beta$-Phenäthylbiguanid ( $\mathrm{W} 32$ ) auf den Alloxanund Phlorrhizin-Diabetes und die intestinale Glucoseabsorption von Ratten. Naunyn-Schmiedebergs Arch. exp. Path. Pharmacol. 244, $31-47$ (1962).

18. - Willms, B., Caspary, W.F.: The mechanism of action of the blood glucose lowering biguanides. In: Reports on Oral Diabetes Therapy, a Selection of Papers presented at the $7^{\text {th }}$ Congress of the International Diabetes Federation, Buenos Aires, August 1970, publ. by Excerpta Medica, Amsterdam, 1971, p. 95-106. 
19. Czyzyk, A., Lawecki, J., Sadowski, J., Ponikowska, J., Szczpanik, Z.: Effect of biguanides on intestinal absorption of glucose. Diabetes 17, 492-502 (1968).

20. - - Untersuchungen über den Einfluß von Phenäthylbiguanid auf den Verlauf von Belastungsproben mit Insulin, Tolbutamid und Glucose bei Diabetes mellitus. Diabetologia 2, 62-67 (1966).

21. Förster, H., Hager, E., Mehnert, H. : Der Einfluß von Butylbiguanid im Tierversuch auf die Resorption von Glucose und Fructose. Arzneimittel-Forsch. 15, $1340-1344(1963)$

22. Ghareb, A., Botros, M., Saba, J.A., El-Asmar, F.A. El-Shawarby, K., Wahba, N.: Mechanism of action of biguanides on glucose metabolism. Ain Shams Med. J. 20, 313-318 (1969).

23. Hollobaugh, S.L., Rao, B., Kruger, F.A. : Studies on the site and mechanism of action of phenformin. I. Evidence for significant "non-peripheral" effects of phenformin on glucose metabolism in normal subjects. Diabetes 19, 45-49 (1970).

24. Kruger, F.A., Altschuld, R.A., Hollobaugh, S.L.: Studies on the site and mechanism of action of phenformin. II. Phenformin inhibition of glucose transport by rat intestine. Diabetes $19,50-52(1970)$.

24a. Levinson, R.A., Englert, E. jr.: Intestinal absorption of sugars, water and sodium in alloxan diabetic rats. Diabetes 19, 683-687 (1970).

25. Love, A.H.G.: The effect of biguanides on intestinal absorption. Diabetologia 5, $422(1969)$.

26. Olson, W.A., Rosenberg, I.H. : Intestinal absorption of sugars and amino acids in diabetic rats. J. clin. Invest. 49, 96-105 (1970).

27. Roe, I.H., Rice, E.W.: A photometric method for the determination of free pentoses in animal tissue. J. biol. Chem. 173, 507-512 (1948).
28. Schäfer, G.: Site-specific uncoupling and inhibition of oxidative phosphorylation by biguanides II. Biochim. biophys. Acta 172 334-337, (1969).

29. Vinnik, I.E., Kern, F., Sussman, K.E.: The effect of diabotes mellitus on glucose absorption by the small intestine in man. J. lab. clin. Med. 66, 131-136 (1965).

30. Wick, A.N., Mobley, P.W., Stewart, C.J.: The hydroxylation of $\beta$-phenethylbiguanide and some effects of p-hydroxy- $\beta$-phenethylbiguanide. Excerpta Medica, International Congress Series 209, 154-155 (1970).

31. Willms, B., Creutzfeldt, W.: Intestinal Absorption of Vitamin $B_{12}$ (Schilling Test) and D-Xylose during oral Therapy with different Biguanide Derivatives In: Reports on Oral Diabetes Therapy, a Selection of Papers presented at the $7^{\text {th }}$ Congress of the International Diabetes Federation, Buenos Aires, August 1970, publ. by Excerpta Medica, Amsterdam, 1971, p. 230-234.

32. Wilson, T.H., Wiseman, G.: Metabolic activity of the small intestine of the rat and the golden hamster. $J$. Physiol. 123, 116-130 (1954).

33. Yoh, Y.-J.: Distribution of $\mathrm{n}$-butylbiguanide $-{ }^{14} \mathrm{C}$ hydrochloride in mouse tissues. Jap. J. Pharmacol. 17, $439-449$ (1967).

Dr. W. F. Caspary

Prof. Dr. W. Creutzfeldt

Division of Gastroenterology

and Metabolism

Dept. of Medicine

University of Göttingen

D-3400 Göttingen

Humboldt-Allee 1

Deutschland 